\title{
IMPROVED FOLK INSTRUMENTS AS A FACTOR OF HOLISTIC SYSTEM OF ACADEMIC MUSICAL AND INSTRUMENTAL CULTURE OF OUR TIME
}

The purpose of the work is to determine the logic of the musical-historical process of academization of the improved bayan/accordion, domra, balalaika, and bandura of the second half of the 20th - the beginning of the 21st centuries. The methodology of the study involves the use of aesthetic-cultural, comparative, theoretical and historical methods, as well as the analytical approach, which form a unified methodological basis. Along with the complex method, a socalled system approach is needed, which allows the object to be comprehensively studied at the most diverse, but interrelated levels. The scientific novelty of the work appears in the expansion of ideas about the genesis and functioning of academic musical and instrumental art as a holistic artistic, culturological and musical phenomenon, taking into account the key role of performing forms of being in the present and the need to update the instrumental-sound phono-sphere of modernity, which is immanently consistent with socio-historical, performing and timbre-textual properties of the advanced folk instruments of our country. Conclusions. The logic of the musical-historical process of academization of bayan/accordion, domra, balalaika and bandura reveals the socio-historical, artistic-aesthetic, instrumental-performing and culturological prerequisites of the phenomenon, among which the author specifically highlights the demand for "fresh" instruments by the very composer's creativity in change of its paradigms in favor of the emancipation of sound; immanent readiness of the "musicians playing folk instruments" to improvise-experimental acts of "sound search"; perspective for the academic phono-sphere of the "ultimate" chamber nature of plucking instruments.

Key words: musical instrument, improved folk instruments, academic musical and instrumental culture, academic music.

Черноіваненко Алла Дмитрівна, кандидат мистецтвознавства, доцент, професор кафедри народних інструментів Одеської національної музичної академії ім. А. В. Нежданової

Удосконалені народні інструменти як чинник цілісної системи академічної музичноінструментальної культури сучасності

Мета статті полягає у визначенні логіки музично-історичного процесу академізації удосконалених баяна/акордеона, домри, балалайки, бандури другої половини XX - початку XXI століть. Методологія дослідження передбачає застосування естетико-культурологічного, компаративного, теоретичного та історичного методів, а також аналітичного підходу, які утворюють єдину методологічну основу. Поряд з комплексним методом необхідний і так званий системний підхід, що дає змогу на самих різних, але взаємопов'язаних рівнях, всебічно вивчити об'єкт. Наукова новизна полягає у розширенні уявлень про генезис і функціонування академічного музичноінструментального мистецтва як цілісного мистецького, культурологічного та музичного феномена з урахуванням ключової ролі виконавських фрорм буття музики у сьогоденні та необхідності оновлення інструментально-звукової фоносфери сучасності, чому іманентно відповідають соціально-історичні, виконавські й тембрально-фрактурні властивості удосконалених народних інструментів нашої країни. Висновки. Визначена у статті логіка музичноісторичного процесу академізації баяна/акордеона, домри, балалайки, бандури виявляє соціально-історичні, художньо-естетичні, інструментально-виконавські, культурологічні передумови явища, серед яких автор спеціально виділяє затребуваність «свіжих» інструментів самою композиторською творчістю в зміні ії парадигми на користь емансипації звуку; іманентну готовність «народників» до імпровізаційно-експериментальних актів «пошуку звуку»; перспективність для академічної фоносфери «гранично» камерної природи щипкових.

Ключові слова: музичний інструмент, удосконалені народні інструменти, академічна музичноінструментальна культура, академічна музика.

Черноиваненко Алла Дмитриевна, кандидат искусствоведения, доцент, профрессор кафедры народных инструментов Одесской национальной музыкальной академии им. А.В. Неждановой

Усовершенствованные народные инструменты как компонент целостной системы академической музыкально-инструментальной культуры современности

Цель работы заключается в определении логики музыкально-исторического процесса академизации усовершенствованных баяна / аккордеона, домры, балалайки, бандуры второй половины XX - начала XXI веков. Методология исследования предполагает применение эстетико-культурологического, сравнительного, теоретического и исторического методов, а также аналитического подхода, которые образуют единую методологическую основу. Наряду с комплексным методом необходим и так называемый системный подход, позволяющий на самых разных, но взаимосвязанных уровнях всесторонне изучить объект. Научная новизна работы выявляется в расширении представлений о генезисе и функционировании академического музыкально-инструментального искусства как целостного художественного, культурологического и музыкального феномена с учетом ключевой роли исполнительных форм бытия музыки в настоящем и необходимости обновления инструментально-звуковой фоносферы современности, чему имманентно соответствуют социально-исторические, исполнительские и тембрально-фактурные свойства усовершенствованных народных инструментов нашей страны. Выводы. Проанали-

(c) Chernoivanenko A., 2018 
зированная в статье логика музыкально-исторического процесса академизации баяна / аккордеона, домры, балалайки, бандуры выявляет социально-исторические, художественно-эстетические, инструментальноисполнительские, культурологические предпосылки явления, среди которых автор специально выделяет востребованность «свежих» инструментов самим композиторским творчеством в изменении ее парадигмы в пользу эмансипации звука; имманентную готовность «народников» к импровизационно-экспериментальным актам «поиска звука»; перспективность для академической фоносферы «предельно» камерной природы щипковых.

Ключевые слова: музыкальный инструмент, усовершенствованные народные инструменты, академическая музыкально-инструментальная культура, академическая музыка.

Relevance of research topic. Modern musicology, performing-theoretical, cultural and some other scientific fields represent a rather variegated picture in the definition of genre-style types of musical creativity and the corresponding conceptual-categorical apparatus. This largely concerns the functioning of the academic musical and instrumental culture of the present, which the author of this article considers as a holistic phenomenon, a fundamentally new system that is not simply a sum of knowledge about instrumental music, musical instruments, composer and performances of instrumental expressiveness, and finally the philosophy of musical instrumentalism (the latter is specially accented by I. Nazin [11]). In the given system of academic musical and instrumental culture of the last third of the 20th - beginning of the 21st century, the academic, yet still so-called folk instrumental art (in its performing, composer, instrumental-organological, scientific and theoretical aspects) is distinguished by the qualities of the "strain" of development, inherent (because of the recent, "in the eyes of the living generation" of the origin of the improvisational, folklore type), the openness to various types and polytypic genre-style phenomena of musical creativity, theatricalization, at the same time showing all the necessary academic positions of music. The discovery of such specific and general parameters of musical and instrumental academism is an actual cut of the scientific research of the present.

The purpose of the study is to determine the logic of the musical-historical process of academization of the improved bayan/accordion, domra, balalaika, and bandura of the second half of the 20th - the beginning of the 21 st century.

Presentation of the main materials. First of all, in the context of the rising problem, it is necessary to consider the concept of academic music and academic musical and instrumental culture. As V. Holopova notes, "in our time, when the word" music "is pronounced, there is definitely a need for clarification - which music: jazz, variety, academic, traditional, oriental or other" [15, 1]. However, "the division of music into" light "and" serious "remains fundamental, despite the various attempts to synthesize one another" [ibid.]. D. Kabalevsky, I. Stetsyuk, M. Abakumov and others also note the most radical general division of music into "serious" and "easy" [10]. Obviously, under the first group (or kind) the researchers have in mind the academic, classical, "high" music, etc. (in German terminology - E-Musiik - Egnest Musiik), under the second - the mass, popular, amateur, entertaining one (U-Musiik - Unterhaltungsmusik). V. Kholopova notes that in the 20th century cultural studies these two types are defined as "academic" music (including "academic avantgarde") and "non-academic". However, for some time, in domestic science prevailing somewhat different dualism in the distribution of music: on vocal-composing (opera-symphonic, chamber vocal and instrumental) creativity and musical folklore (folk music) [9, 887], noted by well-known researcher of traditional instrumental work I. Matsievsky: "One way or another in the professional and amateur artistic creativity of European peoples, two branches of instrumental art were formed: 1 ) academic, connected with the European musical system, the practice of functioning, education, genre- and shaping; 2) unscriptural, connected with the specific national standards of being and structuring, as well as entering into a range of phenomena of traditional art. The first will be called the academic one, the second - the folk instrumental music "[8, 28]. Today, in the world musical culture, there are three distinct categories that are called "layers" by V. Konen. The first of them is the folklore; the second is the composer opera and symphony art. Especially the researcher highlights "third stratum", many types of which differ from each other "and aesthetics, and the type of peculiar professionalism, and for belonging to different national cultures and historical periods" [4, 4], which exists entirely independently as between the two first, distances itself from both, although interacting with them, is developed in accordance with its own laws. In connection with the specificity of musical instrumentalism, L. Mazel's reference to three "stadiums" of the development of musical art is also interesting: "musical folklore"; "oral professionalism" (including "an unwritten sphere of professional instrumentalism," according to I.Matsievsky); professional European composer culture [7] - understood not as chronologically changing stages of development, but as different types (systems) of music.

However, in the practical musical way of life, there is a rather colorful picture of the specific notions of music, among which there are formed something like stable pairs-antinomies according to genre-style, historical, instrumental-organological, national features, performing arts, ideological-figurative content (folklore - academic, folklore - composer, mass - elite, professional - amateur, variety - classical, serious - entertaining, western - eastern, old - modern, secular - spiritual, vocal - instrumental, individual and author anonymized - traditional, oral - written tradition, applied - autonomous, music as a work (Opusmusik) - and both activities, etc."); and semantic crossings leading to synonymization (classic, serious, academic, folkloric, traditional, folk, national, entertaining, light, mass, popular, relevant, popular, etc.); as well as various synthesized titles - popular academic, variety jazz, folk jazz and others. All of them are thoroughly analyzed in the dissertation of A. Kulish, performed under the scientific guidance of the author of this article [5]. Without 
going into details about the coverage of the first and third layers of music, let's move directly to the second one - the academic ("professional composer creativity of the European tradition", by V. Konin [4, 27]).

The key positions in the definition of this type of musical work in various researchers (the works of $\mathrm{V}$. Konin [4], V. Kholopova [15], A. Zucker [16], Y. Loshkova [6], A. Kulish [5] and others) are the following: complex professionalism, "marked by its unique features" [4, 24]) - "professional autonomy" (G. Eggebrecht [citation for 16]), unlike the national, where both professionals and nonprofessionals act (however, with regard to instrumental performances in the folkloric tradition, professionalism, and rather complex, is also an important principle [8]); ideological-spiritual (the connection of this layer with high spheres of the spirit in the social and ideological-figurative aspects) and musical-technological (the principle of notation, the law of close and continuous coming, semitone tempered system, strictly organized polyphony, thinking of large-scale concepts) continuity from the temple musical practice, which justifies the use of the terms as "serious" or "high" music; written form of fixing of the author's (composing) text, which includes "a high degree of ordering of the main components of artistic communication, the stability of the relationship of the composer, performer and listener, which form sustainable forms of existence with all modifications," according to A. Zuker [16]; the latter is closely linked to genre continuity, "which extends through the centuries" [ibid], as well as the phenomenon of opus, a musical work (which has been challenged in recent decades due to the strengthening of the role of the performer and the change of paradigms of composers' means); finally, the European tradition, expressed as an indication of its origin, and its continuity later created by the national composers' schools.

V. Konen, systematizing the "specific, indisputable features of the music school opposing the genres of the 20th century" and folklore, puts forward the name of "professional composer creativity of the European tradition", immediately suggesting that it should be reduced $[4,27]$ and arguing his objection to the term "academic" by the fact that the latter "by virtue of certain traditions ... means the cultivation of the runaways in the past and frozen in its development of rules" [4, 19]. However, the term "academic music" (tradition, culture) is more concise (and widespread), given the high purpose of the first musical academies (from the $\mathrm{XVII}$ century.), the essence of the term is more determined than inevitable in any phenomenon conservatism. The definition of the concept of "academic music" is still an open process, although in the musicology and performing practices it is actively used (often confusing or synonymizing with the concepts of classical, high, European composer, opera-symphonic, professional, etc. - their comparison is carried out in the dissertation A. Kulish [5], absolute). Wikipedia's Folk Thought offers the following definition: "Academic music is music that is inherited from, first of all, formed in Europe in the seventeenth and nineteenth centuries musical genres and forms (opera, symphony, sonata, etc.), melodic and harmonious principles and instrumental composition "[1]. This definition effectively removes from the academic rocks a huge layer of professional composer music - aleatory and other techniques of modern composition, with an open form, mobiles, etc. In the thesis of A. Kulish under academic music means "professional European composer music of written tradition, which has the following" square "of value criteria proposed by V. Kholopova: positivity, size, originality, completeness of expression, as well as the music of national composer schools that arose in imitation of the mentioned European one"[5] (note that V. Holopova subsequently added to these ethical and aesthetic criteria the fifth" - psychological one: the desire to return to the heard more than once "[15]).

The formation of the same academic music chronologically coincides with the development of the XVIII century, firstly, the aesthetics of science (the science of sensual knowledge, by A. Baumgarten, and the science of the beautiful), and secondly, the emancipation of musical instrumentalism. In this connection, we should call the European term "absolute music" associated with the distraction of music as such "from everything except its own musical nature and elevated above the functional purpose" [15, 6]. Moreover, in the 19th and 20th centuries "... for the reason that the instrumental music is devoid of association with the text and the program, the listener requires especially deep attention, especially concentrated listening, it, according Dalhous, eventually replaces church music at the level of the "holy art" [17, 143]. The term "absolute music" (absolute Musik) at the turn of the eighteenth and nineteenth centuries was nominated for the definition of a new musical phenomenon of "music with an angry word" (instrumental, saturated with living language intonations and speech-language logic of their relations) by the German aesthetic thought (more on this [15; 18]). Thus, that was the end of the formation of autonomous music, "capable of expressing everything and not requiring any support." The notion of "absolute music" played an important role in affirming the "instrumental paradigm" of music on the theoretical and practical levels; in its context the phenomena and concepts were studied, as well as the fundamental properties of music as a form of art, such as "unpredictability", "inertia", "inner essence", "pure content", "ideationality", "uplift", "poetic", "the spirit of the world", "infinity", "infinite melody", "infinite harmony", "new aesthetics of the number", "specific music", etc. However, in the native musicology the term did not fit, although there was the expression "pure, unprogrammed instrumental music". For the declared in the beginning of the article the phenomenon of instrumental academic culture (where we also include "software" instrumental music), this term does not cover the entire completeness of the phenomenon. As for the definition of "academic musical and instrumental culture", it involves the quality of structured integrity (R. D. Benedict, Y. Bychkov, G. Gachev, M. Kagan, A. Mol, I. Nazina, A. Sokolova, etc.). If the concept of music is "... historical. It is constantly changing. The fact that yesterday was not yet music, at the end of a certain time it becomes it... it does not exist ... out of touch with human culture ... arises and develops within the framework of culture, performs certain functions in it, and occupies a certain 
place in it " [2], then the "cultural model" of academic art, "taking into account statics and dynamics, is more detailed and ramified and clearly demonstrates the explicit and hidden interrelations between subsystems and elements" $[14,18]$ of this holistic, peculiar, independent artistic and aesthetic, difficult-professional, material-substantial [19] and philosophical and mythological phenomenon [18; 12] (V. Kholopova directly calls the academic music "culture" in contrast to "light" species - "subcultures" [15, 11]).

For the academic instrumental culture, the above mentioned positions of academic music are fundamental. And if the principle of "opus", individual authorship (in favor of co-authorship with the performer, but not the objections as such) is violated with the emergence of a laity and open form, then the "European" can now be questioned (for example, the American minimalists directly borrowed "a rehearsal method "From the musicians of India and Africa), then the value criteria (positivity, size, originality, completeness of expression, the desire to return) and syntactic processing of the intonational material (even avant-gardist V. Lytoslavsky quickly returned to the concept of motive with the corresponding syntactic registration) form the basis of academic music. Obviously, the Saponov's most important conclusion about "the only written musical culture in the world (European professional - AC) as a factor of its" universality and world-wide universality of artistic values ", a special" concept of musical art ", other aesthetic criteria, psychology, auditory tuning and special methods of professional training remains a live issue $[13,4]$. The complex professionalism remains incompatible (due to the need to master a number of specific, non-domestic skills and forms of instrumental movements, expressive intonation, artistry - inherent in instrumental culture and its folkloric expression).

In the stable communicative triad of academic music (composer - performer - listener) the author remained the main figure for a long time. Without detracting from the importance of author's composer's creativity, we note that today researchers are increasingly talking about increasing the role of performing arts and in the academic field - in comparison with folklore and "third stratum". It is significant that the greatest number of coincidences in the characteristics of various, including the polar, specific parameters of musical and instrumental culture refers to the genre-stylistic indicators, and recognition, the characteristic differences affect, first of all, the performing style of instrumentalists and, to a lesser extent, the tools themselves. That is, today the performer chooses the direction, manner, and style of the game, consistent with their own passions, possibilities, tastes, revolutionary finds, as well as listening interests and a vector of contemporary art trends. Thus, the very performing forms of today music being form the actual directions of its development. The performer, directly communicating with the public, thoroughly feels its advantages, and the ways and forms of influence on it in terms of aesthetic and spiritual enrichment. In the creative biography of one performer sometimes there is a "matching incompatible" in the performance of various genre-type (academic, folk, jazz, etc.) compositions.

For example, due to some reasons (revolutionary reconstruction of the instrument, immanent theatricalization of this type of instrumentalism, asceticism and charisma of the personality of the performers, the typical degeneration of this kind of art into the chamber form, the active appeal to the instrument of the composers of the highest echelon), it largely refers to bayan players. We will add here a Bayan to the "genetic" with the "visible" because of a small evolutionary-time interval with folk and popular mass roots (where the singer is a key figure) and compelled, due to the lack of an original repertoire, the inclusion of the bayanists in the composer's process (traditional composer education is based on knowledge of other instruments). Recent positions are also related to improved domra, balalaika and bandura. Traditionally guitar creativity is developing poly-stylistically. Thus, in the academic folk instrumental music, the role of the performing component is initially large (reflecting the current state of the genre in general). And "forgotten" during the academization of musical instrumentalism (in favor of orchestration), the luvian-harpsichord plucking of domra, balalaika and bandura today is both a "new" and an "old" new quality of the benefits of the "recruits"academists in poly-stylistic, innovative, sound and various neo-trends.

In addition, for instrumental music culture, the instrument itself, on which the composer's or coauthored (with the performer) music is played, which, on the one hand, forms the embodiment of the musical idea in the concrete forms of the organization of the intonational material (today - with the demand to find a new sound, up to appealing to new instruments-figurants), on the other hand - instrumental music itself is influenced by the instrument - its timbre, articulation, dynamic, sonorary, organo-logical, historical and mythological characteristics.

Today musical instruments as material objects of culture are actualized-personified not only in the psychology of the performer (all known "relations" of the instrumentalist with his instrument) and "instrumental theater," but also in the direction of the so-called philosophy of instrumentalism, which has gained momentum in recent times (there is more about this in the works of Belarusian scientist I.D. Nazina, which includes such a philosophy to the pentade of traditional instrumental culture along with homo musicus (human musical), musical instruments, performances, instrumental music [11]). For the academic musical and instrumental culture, inclusion in the "system" of performing art (co-creation) and musical instrument is also relevant (composer - performer + instrument - listener). XX century attracted the composers to a new sonorous space, deep into the sound matter, to the "emancipation of sound" (L. Gakkel), the kingdoms of nontranslatable timbre formulas (as the reverse side of globalization-universalization), and here "Mr. Instrument" plays a far-reaching role - he can instruct himself, and may sometimes even dictate to the composer, the performer and even the listener not only means but also ideas, directions of their development. 
We agree with D. Varlamov's statement that "academic musical art, as well as folklore, is a movement, not a state. The laws of this movement are universal: they obey the known evolutionary laws "[3]. This author regards academia as "as a process of art movement, the transformation of disparate ethno-social cultures into a global type of universal art called academic" "[ibid.]. However, the academy, which really "keeps on" with universalization, does not deny the parallel process of specification of instrumental means of expressiveness characteristic of the modern stage of musical art (for example, the creation of "invisible texture formulas" on all instruments). [19] Actually, this counter trend confirms also the academization of advanced folk instruments of the Slavic countries in the second half of the twentieth century - the "fresh blood" of the new timbrality in the "body" of several centuries of academic instrumentalism (in Europe, the bayan/accordion and guitar originally began the parallel paths of academic and folklore, popular and mass cultures). Of course, their academization is largely associated with performing enthusiasm, but the "old European art" needed just such "surrender", corresponding to the "century of timbrality" in the foreseeing of B. Asafieva. We believe that the viability of any type and genre of art, including musical folklore, academic, "third layer", directly depends on the degree of heuristic in the optimal coincidence with canonical tradition. Any phenomenon is not insured against a negative post-syndrome (D. Varlamov points to the "academic post-syndrome" as "the unification of musical thinking and activities ... typing, standardization, thinking of stamps ... and leveling up of national identity" [3]) In terms of the same degree of heuristic, openness to innovations, improved folk instruments as "recruits" are distinguished by the beneficial qualities of enthusiasm and "freshness".

Conclusions. The logic of the historical process of music and folk instrumentalism academization as a reasonable, objective, legitimate reason being, but having a "metaphysical structure" (by Spengler), reveals the following options. We agree with $\mathrm{h} \mathrm{D}$. Varlamov in the identification of socio-historical (the revival of national consciousness, orientation to a wide audience, development of instrumental and constructive thought) and internal artistic and aesthetic (the formation of intonational thinking of the people and new artistic and aesthetic poses in the public consciousness, the flowering of domestic culture, penetration into the folk practice of written methods of storage and transmission of musical information, creation of improved designs of folk instruments) prerequisites for the emergence of phenomena for the academization of instrumental-national-instrumental art, we would like to add a few factors of the conditionality, naturalness and inevitability of this process.

1. From the standpoint of the theory of contemporary composition, it is worth noting the strengthening of the trend of finding a "new sound" in the context of the allocation of the latter in a special significant artistic field. In this connection, "fresh", but tested on academic career instruments - bayan/accordion, domra, balalaika, bandura (as "aspiring" original and new repertoire performers on them) were "at the right time place ". The folk "trail" of the origin of these instruments only contributed to the immanent readiness of the "folk instrument players" to improvise-experimental acts of "sound search" in co-production with composers. Without going into details, we especially note the portability, design, texture and features of planting this type of instrumentalism in today's organization of sonorous material. In the area of searching for new sound, the bayan essentially outperforms the "extreme" chamber in sound production, tonality, articulation, dynamics, and pinch plot. The last ones are, in our view, a huge academic perspective of phono-sphere confirmed by the expressions and music of such composers as S. Gubaidulina, M. Zaitseva, E. Podhaytsa, A. Kusyakova V. Zubytsky, Y. Gomelska etc.: meaning pizzicato and tremolo sonority of the "secondary cantilena" (a term of Petryk V. [12]), not to mention the possibility of numerous original "unmovable" instrumental articulatorytexture techniques.

2. "Above chamber character" of the plucked instruments, unique timbrality of plucked and it is fresh and organic to current day (in conceptual and philosophical and acoustically-phonic plans) issue of emancipation silence. Characteristically, this phenomenon is mainly realized precisely by instrumental and musical means, which is associated with objective factors: instrumental silence captures a specific absoluteness of silence (with complete negation of the earth's sound environment - breathing, involuntary motion, coughing, etc.) and, simultaneously, a full objective (independent of human physical processes) will to go out from the state of silence the state of sound (at that of art, to which the musical instrument is designed) hyperbolizing the phenomenon of "doing" it, a manifestation of skill. In this case, special forms of musical and instrumental performances are acquired (playing in the air, silent press of the keys or instrument valves, etc.), their theatrical visual hyperbolization, which helps to embody the "otherness" of sonorous tones and themes in their artistic diversity. Portable design, bayan/accordion, domra, balalaika, bandura in a concert landing do not restrict the artist's facial expressions and unfolds to the audience in such a way that the playgrounds of instruments and performing movements completely bring this additional expressive means of silence to the audience.

3. The described visual-demonstration of the design, landing, playing performances, and the "loop" of natural folklore improvisation-theatricality, allowing the bayan/accordion, domra, balalaika and bandura to be in line with the actual trend of theatricalization of musical art, perhaps to a greater extent than other academic "brothers". 
4. Organically parallelism of the existence of the bayan/accordion in popular, pop-jazz, folklore; bandura, domra, balalaika (the last two are rarer in the twenty-first century) in folklore spheres "works" - against the backdrop of postmodernist poly-stylistic tendencies.

5. Let's remind that, as well as academic, folklore instrumentalism has a high degree of professionalism. Therefore, the transformation of the art of the playing on improved bayan/accordion, domra, balalaika, bandura (with parallel existence in the folklore and popular fields) into academic instrumental culture is a more "short transition" from the radius of one professional skill to the radius of another (similar to the geometric parable of Avva Dorofiy).

\section{תimepamypa}

1. Академическая музыка. Википедия. URL : https://ru.wikipedia.org/wiki

2. Бычков Ю. Понятие "Музыка". Периодизация становления и развития музыкального искусства // Вопросы музыкознания : Теория. История. Методика / МГИМ им А. Г. Шнитке ; кафедра теории и истории музыки. Москва, 2010. Вып. III. С. 9-26.

3. Варламов Д. Становление академической традиции в русском народно-инструментальном искусстве XIX столетия : [учеб. пособие]. Саратов : СГК, 2010. URL : http://www.general-ebooks.com/book/2962407

4. Конен В. Третий пласт : новые массовые жанры в музыке XX века. Москва : Музыка, 1994. 160 с.

5. Кулиш А.Н. Актуальные исполнительские фрормы сербского баянно-аккордеонного искусства : дис. ... канд. искусствоведения. 17.00.03. Одесса, 2013. 192 с.

6. Лошков Ю. Професійне музичне мистецтво в понятійному просторі // Культура України : зб. наук. ст. Харків : ХДАК, 2008. Вип. 22. С. 141-152

7. Мазель Л. О природе и средствах музыки. Москва, 1991. 209 с. 2007. $520 \mathrm{c}$.

8. Мациевский И. Народная инструментальная музыка как феномен культуры. Алматы : Дайк-пресс,

9. Музыкальный энциклопедический словарь / Гл. ред. Г.В.Келдыш. Москва : Советская энциклопедия, 1990. 672 с. : ил.

10. Надолинская Т. Проблемы и перспективы изучения популярной музыки в современной школе // Международный интерактивный сетевой семинар «Интегративные процессы в современном образовании». 2011. URL : http://www.art-education.ru/project/seminar-2011/nadolinskaya/nadolinskaya.pdf

11. Назина И. Д. О базисных концептах исследования традиционной музыкально-инструментальной культуры Беларуси // Вопросы инструментоведения. Санкт-Петербург, 2004. Вып. 5. Ч. 1. С.55-61

12. Петрик В.В. Категория инструментализма в музыкальном творчестве (на примере домрового искусства) : дис. ... канд. искусствоведения. 17.00.03. Одесса, 2009. 197 с.

13. Сапонов М. Искусство импровизации. Москва, 1982. 77 с.

14. Соколова А.Н. Традиционная инструментальная культура западных адыгов: системнотипологическое исследование : автореф. дис. ... доктора искусствоведения. 17.00.02. Санкт-Петербург, 2006. 40 c.

15. Холопова В. Понятие «Музыка» // Музыкальная Академия. 2003. № 4. С. 1-18.

16. Цукер А. Проблемы взаимодействия академических и массовых жанров в современной советской музыке : автореф. дис. ... доктора искусствоведения : 17.00.02. Москва, 1991. 48 с.

17. Чередниченко Т.В. Тенденции современной западной музыкальной эстетики : монография. Москва : Музыка, 1989. 229 с.

18. Черноіваненко А. Поняття «абсолютна музика» у розвитку музичного інструменталізму // Музичне мистецтво і культура : Науковий вісник ОНМА ім. А.В. Нежданової : [зб. наук. статей / гол.ред. О.В, Сокол]. Одеса : Астропринт, 2014. Вип. 19. С. 212-224.

19. Черноиваненко А.Д. Фактура в выявлении выразительных возможностей баянной музыки : дис. ... канд. искусствоведения : 17.00.03. Киев, 2002. 166 с.

\section{References}

1. Academic music. Wikipedia (2011 April 7). Retrieved from https://ru.wikipedia.org/wiki

2. Bychkov Yu. (2010). The concept of "Music". Periodization of the formation and development of musical art. Questions of musicology: Theory. History. Methodology, III, 9-26 [in Russian].

3. Varlamov D. (2010). Formation of the academic tradition in Russian folk-instrumental art of the XIX century Retrieved from http://www.general-ebooks.com/book/2962407 Russian].

4. Konen V. The third layer: new mass genres in the music of the XX century. Moscow: Music, 1994 [in

5. Kulish A.N. (2013). Actual performing forms of Serbian accordion-accordion art. Candidate's thesis. Odessa: ONMA them. A.V. Nezhdanova [in Ukraine]

Ukrainian]

6. Loshkov Yu. Profesiyne muzichne mystetztvo in ponyatiynomu prostori. Culture of Ukraine, 22, 141-152 [in

7. Mazel L. On the nature and means of music. Moscow, 1991 [in Russian] Russian].

8. Matsievsky, I. (2007). Folk instrumental music as a phenomenon of culture. Almaty: Dike press [in

9. Keldysh G.V. (Eds.). Music Encyclopedic Dictionary. Moscow: Soviet Encyclopedia, 1990 [in Russian].

10. Nadolinskaya T. (2011) Problems and perspectives of studying popular music in a modern school. International interactive network seminar "Integrative Processes in Modern Education" Retrieved from http://www.arteducation.ru/project/seminar-2011/nadolinskaya/nadolinskaya.pdf

11. Nazina I.D. (2004). About the basic concepts of research of traditional musical and instrumental culture of Belarus. Problems of Instrumentology. (Vols. 5), (pp. 55-61). St. Petersburg [in Russian]. 
12. Petrik V.V. (2009). The category of instrumentalism in musical creativity (on the example of the housebuilding art). Candidate's thesis. Odessa: ONMA them. A.V. Nezhdanoev [in Ukrainian].

13. Saponov M. The art of improvisation. Moscow, 1982 [in Russian].

14. Sokolova A.N. (2006). Traditional instrumental culture of the Western Adygs: system-typological study. Extended abstract of candidate's thesis [in Russian].

15. Kholopova V. The concept of "Music". Music Academy, 2003, 4, 1-18 [in Russian].

16. Zucker A. (1991). The problems of interaction of academic and mass genres in contemporary Soviet music. Extended abstract of Doctor's thesis. Moscow [in Russian].

17. Cherednichenko T.V. (1989). Trends in contemporary Western musical aesthetics. M.: Music [in Russian].

18. Cherniovanenko A. (2014). The notion of "absolute music" in the development of musical instrumentalism. Muzychne mystetsvo i kultura, 19, 212-224 [in Ukrainian].

19. Chernoivanenko A.D. (2002). The texture in revealing the expressive possibilities of bayan music. Candidate's thesis. Kiev [in Ukrainian].

Стаття надійшла до редакції 16.08.2018 p.

УДК 78.03

Шевченко Лілія Михайлівна

кандидат педагогічних наук, доцент, доцент Одеської національної музичної академії імені А.В.Нежданової

ORCID 0000-0001-8602-9573

\section{ЛІРИЗМ УКРАЇНСЬКОÏ МЕНТАЛЬНОÏ УСТАНОВКИ ТА ІІЇ МУЗИЧНЕ ВИЯВЛЕННЯ}

Метою дослідження виступає виявлення специффіки ліризму як ментально-соціальної якості українства і своєрідності її втілення в музичній сфрері. Методологічною основою дослідження виступає інтердисциплінарний мислительно-стильовий компаратив і культурологічно-герменевтичний спосіб значеннєвої інтерпретації відповідних побудов наукового і музично-творчого мислення у продовження позицій Т.Адорно, О.Лосєва, досліджень О.Сокола, О.Маркової, О.Муравської та ін. Наукова новизна одержаних результатів - теоретично самостійне усвідомлення концентрації національно-ментального виявлення українства у творчому «нон-конформізмі» уникнення артистично-стильового «злиття» національного художнього внеску з жанрово-стильовими парадигмами загальноєвропейського стильового розкладу. Висновки. «Український ліризм» зазначаємо як спосіб мислення, в якому раціоналістична предметна розмежованість значень принципово корегується понадзмістовним «ширянням» емоційних згущень - розріджувань, що надає особливого роду штучного культурного ритму самовираженню носіїв української ментальності. Виділяється психічна парадигма коливань духовної наснаги й душевної жалоби, що впізнанні в сльозно-умилительному містицизмі українського Православ'я, яке минає максималізм «всесвітового спасіння» російського Сходу, уповаючи на безпосередність братства, що визначає одухотворенну понадіндивідуальна душевність українського ліризму. Підкреслюється соціальний феномен «плутанини сцени й життя», який в життєвому виявленні зазначає артистичний тонус суспільних і особистісних рішень, що в мелодійно-пісенному проявленні стверджували морально-організаційні устої нації поза державно-будівничих зусиль і які, можливо, будучи висунутими на перший план національного самоствердження у кінці XX сторіччя, здійснювалися на тлі відсторонення фахівської музики від пісенно-вокального прояву на користь камерно-інструментальної «скромності» своєї заявки у художньому національному бутті.

Ключові слова: ліризм як соціальний феномен, ліризм як якість творчого виявлення, понадіндивідуальна душевність вираження, фахівська музика, популярна художня сфера.

Шевченко Лилия Михайловна, кандидат педагогических наук, доцент Одесской национальной музыкальной академии имени А.В.Неждановой

Лиризм украинской ментальной установки и ее музыкальное проявление

Целью данного исследования выступает проявление специфики лиризма как ментально-социального качества украинства и своеобразности ее воплощения в музыкальной сфере. Методологической основой исследования является интердисциплинарный мыслительно-стилевой компаратив и культурологическигерменевтический способ смысловой интерпретации соответствующих построений научного и музыкальнотворческого мышления в продолжение позиций Т.Адорно, А.Лосева, исследований А.Сокола, Е.Марковой, О.Муравской и др. Научная новизна полученных результатов - теоретически самостоятельное осознание концентрации национально-ментального выявления украинства в творческом «нон-конформизме» избегания артистически-стилевого «слияния» национального художественного вклада с жанрово-стилевыми парадигмами общеевропейского стилевого расклада. Выводы. "Украинский лиризм» обозначаем как способ мышления, в котором рационалистическая предметная разграниченность значений принципиально корректируется надсодержательным «парением» эмоциональных сгущений-разрежений, что придает особого рода искусственный культурный ритм самовыражению носителей украинской ментальности. Выделяется психическая парадигма колебаний духовного сосредоточения и душевной печали, которые узнаваемы в слезно-умилительном мистицизме украинского Православия, минующего максимализм «всемирного спасения» российского Востока, уповающего на непосредственность братства, что определяет одухотворенную надиндивидуальную душевность украин-

() Шевченко Л. М., 2018 